East African Journal of Science, Technology and Innovation, Vol. 2 (2): March 2021.

This article is licensed under a Creative Commons license, Attribution 4.0 International

(CC BY 4.0)

\title{
Natural vegetation regeneration from soil seed banks in the cultivated edges of Sudd wetlands in Juba, Southern Sudan
}

${ }^{1 *}$ ESAETE J., ${ }^{2 B O N G O ~ A ., ~}{ }^{2}$ LADO T., ${ }^{2 B O J O I ~ T ., ~}{ }^{1 B U S U L W A ~ H}$

\author{
${ }^{1}$ Department of Science Technical and Vocational Education, Makerere University \\ ${ }^{2} \mathrm{School}$ of Natural Resources and Environmental Studies, University of Juba \\ *Corresponding Author: esaete@gmail.com
}

\begin{abstract}
Soil seed banks are important for regeneration of degraded wetlands ecosystems. The Sudd wetlands of Juba city have long been encroached for crop cultivation. Seedling germination was monitored in a greenhouse to establish possible natural regeneration in Mindiari, Rejaf and Roton wetlands in the Sudd. Sixty-four species germinated from the soil seed bank of which $12.5 \%$ were dominated by Cyperus difformis and Typha capensis. The findings showed that median wetland species richness in Mindiari was 1.5 (interquartile range $=0.75-3.5$ ), Rejaf 2.5 (interquartile range $=1.0-4.0$ ), Roton 3 (interquartile range $=1.0-5.0)$ while median Shannon-Wiener diversity was $1.5(1.14-1.73), 1.43$ (1.01-1.66), 1.15 (0.98-1.67) for Mindiari, Rejaf and Roton respectively. Both the median seed species richness and diversity were not significantly different among the study wetlands. The median of seed density (56.1) was significantly higher in Roton than in Mindiari (36.7) and Rejaf (29.4) wetlands. The NMDS results showed that species composition of Mindiari and Rejaf was different from Roton. It is concluded that growing crops in wetlands did not influence species richness and diversity but it reduced seed density and altered species composition. Although wetland species were not significantly different in the threewetland categories, dominance of canopy species belonging to Typhaceae and Cyperaceae indicates that these species are resilient to cultivation and could facilitate natural regeneration of cultivated wetlands edges of the Sudd region in Juba. Further research should examine effect of cultivation duration and flooding regimes on soil seed bank species richness, diversity, and density and composition.
\end{abstract}

Keywords: Cultivation disturbance; Regeneration; Sudd; South Sudan; Seed bank; Wetlands

Cite as: Esaete et al., (2021). Natural vegetation regeneration from soil seed banks in the cultivated edges of Sudd wetlands in Juba, Southern Sudan. East African Journal of Science, Technology and Innovation 2(2).
Received:

Accepted:

Published:
$28 / 08 / 20$

$07 / 12 / 20$

$25 / 03 / 21$ 


\section{Introduction}

Wetlands are usually viewed as suitable alternative arable lands for crop cultivation as they have reliable water and fertile soils (Verhoeven and Setter, 2010; Saha and Pal, 2019; Munishi and Jewitt, 2019). Increase in human population coupled with the growing demand for food production land has accelerated wetland conversion to farmlands resulting in wetland degradation and loss. About 33\% of wetlands have been lost globally including $16 \%$ in Africa (Hu et al., 2017). Cognizant of wetland degradation challenges, the Ramsar Convention, (1971) permits sustainable and non-destructive wetland uses including livestock grazing and wetland edge cultivation, which allows natural regeneration from soil seed banks (Ramsar Secretariat, 2013).

However, such regeneration is influenced by site characteristics, proximity to seed sources and intensity of wetland disturbances (Ma et al.,, 2014; Peralta et al., 2016; Shi et al., 2020). Several studies have examined disturbance intensity and natural regeneration of emergent macrophytes from soil seed banks in wetland ecosystems including studies in Australia (Brock, 2011; Grieger et al.,, 2019), Europe (Abernethy and Willby 1994, Klimkowska et al., 2010; Lenzewski et al.,, 2020), Asia (Yang et al., 2018; Chen et al., 2020) and America (Keddy and Reznicek, 1996; Kottler and Gedan; 2020), which have affirmed that wetland soil seed banks are usually associated with high species richness. A study linking hydro period with vegetation response showed that wetland species richness and density was related to flood frequency (Battaglia and Collins, 2006; Shoemaker and Ervin, 2019). Other studies found no relationship between flood frequency, species richness and density in soil seed banks (Capon and Brock, 2006; Webb et al., 2006; Stone et al., 2018; Baskin, Baskin and Chester, 2019) or fewer species in low flood frequency zones (Capon, 2007). Other than flooding, human disturbances such as cultivation in wetlands have increased around the world (McCartney et al., 2010; Rebelo et al., 2010; Chen et al., 2018). Cultivation increases seed turnover rate in the soil seed bank (Baskin and Baskin, 2014) and influences soil seed bank species richness, diversity and density.

The process of wetland cultivation involves removal of vegetation to pave way to crop planting. Vegetation removal reduces species richness, diversity, density and alters composition of soil seed banks as the seed rain changes. On the other hand, sparing vegetation increases seed density through enhanced internal seed inputs to the soil seed bank (Brown and Cahill Jr., 2020). Therefore, the seed bank of least cultivated wetlands tend to have low species richness and diversity but high seed density. Meanwhile moderately and highly cultivated wetlands have limited or no vegetation, which increases chances for germination from the soil seed bank (Brown and Cahill Jr., 2020) and the seed bank, is usually species rich and diverse with low seed density. This implies that cultivation intensity influences natural vegetation regeneration from soil seed bank.

In Europe, Asia and America, studies of natural regeneration from soil seed banks in cultivated wetlands have produced mixed results. Some authors have reported species rich, diverse and abundant soil seed banks in formerly cultivated wetlands enabling natural regeneration (Touzard et al., 2002; Bao, et al., 2014; He et al., 2020). These results imply that the soil seed bank reservoirs in wetlands are resilient during cultivation. In contrast, some studies have reported limited regeneration in cultivated wetlands with low species richness, diversity and density of seeds in the soil seed bank (Galatowitsch and van der Valk, 1996; Wang et al., 2017: Salaria et al., 2018). In Sub-Saharan Africa, studies of wetland regeneration from soil seed banks and disturbance by cultivation are limited and inconclusive. For example, Matayaya et al., (2017) found that species richness was lower in conventional tillage plots in dambo wetlands in Zimbabwe. In East Africa, Gaudet (1977) found no influence of flooding on wetland regeneration 
from soil seed banks in Lake Naivasha in Kenya. Whereas wetlands in other East African countries such as Uganda, Tanzania as well as the Sudd wetland of South Sudan have continued to experience increased degradation by cultivation (Kyalo and Heckelei, 2018; Msofe et al., 2019; Kabiri et al., 2020; Wehling, 2020), there is limited information on soil seed banks and wetland regeneration which provided the impetus to carry out this study.

Wetlands cover about $7 \%$ of the total area of South Sudan and vary in size with the Sudd as the largest wetland (African Development Bank, 2013). The Sudd wetland, associated with the Lake Victoria catchment, is the largest wetland ecosystem in the Nile basin and one of the largest tropical wetlands in the world. It experiences regular floods, which vary with season and rainfall. Habitats within the Sudd wetland consists of submerged and emergent macrophytes, floating and fringing vegetation, seasonally flooded and rain-fed grasslands and floodplain woodlands (Wilusz et al., 2017). Cyperus papyrus, Phragmites communis, Vossia cuspidata, Typha domingensis and Eichornia crassipes (water hyacinth) are common along open water channels and dominate the permanent swamp areas, which are surrounded by floodplains and seasonally flooded grasslands characterized by Oryza longistaminata and Echinochloa pyramidalis. Previous wetland research in the area tended to focus on hydrological regime (Rebelo et al., 2011; Sosnowski et al., 2016; Sutcliff and Brown, 2018) and effects of hydrocarbon contamination on soils (Ruley et al., 2019) while soil seed bank studies have largely been neglected thus curtailing deeper understanding of soil seed banks in the Sudd wetlands of South Sudan. Moreover, there has been limited research in wetlands in the surroundings of Juba City which are experiencing increasing human population growth estimated at $4.61 \%$ per annum (Fernando and Garvey, 2013). The local population is poor and $80 \%$ live on less than USD1 per day (Fernando and Garvey, 2013). The above scenario coupled with changing weather patterns and widespread localized droughts tends to accelerate the encroachment of wetlands for cultivation by the urban poor, which threatens their existence and the biodiversity. Therefore, knowledge of soil seed banks is crucial to broaden understanding of vegetation regeneration in the cultivated wetlands found on the fringes of Juba City. If the wetland vegetation is conserved and allowed to regenerate, inherent functions such as hydrological buffers and provision of food, water, construction materials and grazing areas will benefit the local people in the area. In addition, wetlands' aesthetic value will provide opportunities for nature-based tourism and conservation of the local cultures (Sanna and Eja, 2017; Zhou et al., 2020).

Research on wetland regeneration resonated well with the recently declared United Nations (UN) 2021-2030 Decade on Ecosystem Restoration, which recognizes the need to restore degraded ecosystems such as wetlands throughout the world including South Sudan. Natural vegetation regeneration from soil seed banks would enable cultivated wetlands to regain their functions such as providing goods and service to people. However, natural vegetation regeneration relies mainly on soil seed banks (Saatkamp, Poschlod and Venable, 2014; Vadvik et al., 2015).

The purpose of this study was to investigate the potential for natural vegetation regeneration from soil seed banks of cultivated wetlands in the surroundings of Juba City. The objective of the study was to assess soil seed bank species richness, diversity and density in wetlands differing in cultivation intensity.

\section{Materials and Methods}

\section{Description of study site}

Juba $\left(4.859363^{\circ} \mathrm{N} ; 31.571251^{\circ} \mathrm{E}\right)$ is located west of the River Nile at $457 \mathrm{~m}$ above sea level (Figure 1). It has a tropical wet and dry/savanna climate with the dry season in November to March, and the wet season from April to October. It has an average temperature of $27.8^{\circ} \mathrm{C}$, and an annual average rainfall of $972.4 \mathrm{~mm}$ (Lomeling, 2020). 
The city is situated between River Nile, and the Logwe (Rejaf West), Körök (Kujur) and Nyar Kenyi (Lado) mountains. The surrounding lowlands are prone to repeated flooding from River Nile, Luri River, and others (State of Environment Report, 2018). Juba is the political capital city of South Sudan and administrative headquarters of Central Equatoria State. The city is expanding and Mindiari, Rejaf and Roton wetlands (Figure1) have been encroached for settlements and agriculture. Mindiari wetland $\left(2.48 \mathrm{~km}^{2}\right)$ is located $7.3 \mathrm{~km}$ from Juba city; North West. It lies at $465 \mathrm{~m}$ asl and receives water from seasonal streams such as Luri and Kapuri and eventually drains into river Kriti. The dominant riparian vegetation includes sedges and grasses such as Echinochloa sp., Justicia insularis, Cyperus rotundus, Carex pseudocyperus and trees and shrubs such as Grewia tenax, Balanites aegyptiaca, Acacia sieberiana that are mostly found in the southern and eastern parts of the wetland. Fishing and harvesting of wild vegetables such as Amaranthus sp., and Cleome gynandra (spider web plant) and collecting wild fruits, for example from Grewia tenax, are the main economic activities. In the past, the wetland was a major source of water for wildlife, cattle and goats, which mostly grazed on Echinochloa sp. However, increase in human population in and around
Juba city has resulted in encroachment by crop cultivation and human settlements.

Rejaf wetland $\left(0.526 \mathrm{~km}^{2}\right)$ is located $10 \mathrm{~km}$ in the south east of Juba city; South East. It lies at $461 \mathrm{~m}$ asl and receives water from River Kit during the rainy season. The dominant vegetation includes Setaria megaphylla, Typha domingensis and Cyperus rotundus. The western part of the wetland is covered by woodland dominated by Acacia sieberiana whereas the eastern part is dominated by Balanites aegyptiaca and Ziziphus mauritanica. There is moderate cultivation and livestock grazing on the edges. Roton is a permanent wetland covering $4.39 \mathrm{~km}^{2}$ located $2.7 \mathrm{~km}$ north east of Juba city. It lies at $452 \mathrm{~m}$ asl and receives water from seasonal streams and rivers. It is located on the fringes of Juba International Airport and is the least cultivated due to restricted access. The dominant plant species include Typha domingensis and Alopecurus sp. and Balanites aegyptiaca.

In this study, extent of disturbance as spatial size of area cleared has been categorized as; large when most parts of the wetland is cultivated (Most), medium when moderate area of wetland is cultivated (Moderate) and small when least area of wetland is cultivated (Least) and herein represented in and denoted as Mindiari, Rejaf and Roton wetlands respectively (Figure 1). 


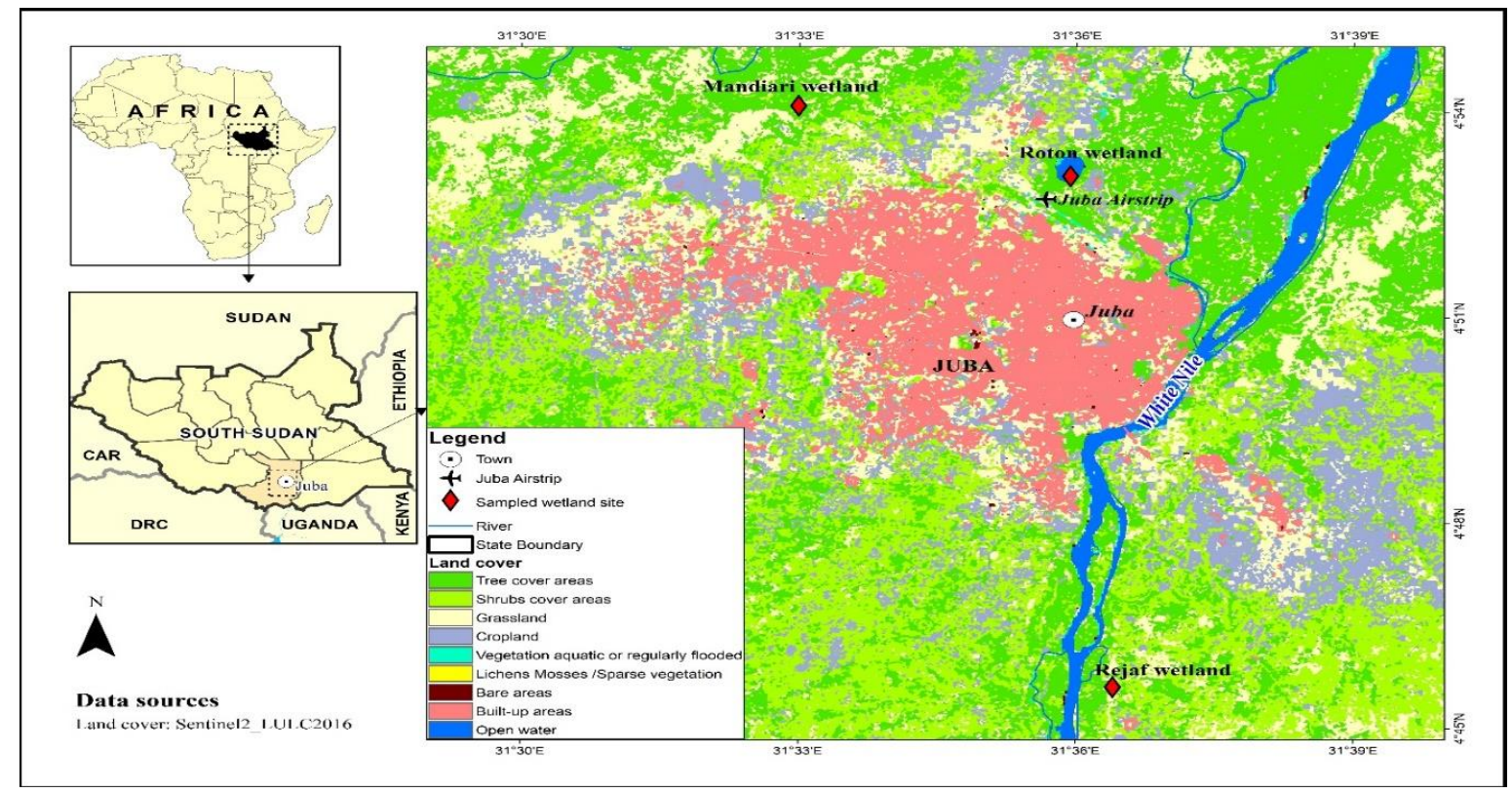

Figure 1. Location of Mindiari, Roton and Rejaf wetlands in the Sudd wetland system, South Sudan.

\section{Materials and Methods}

\section{Soil seed bank sampling}

Mindiari and Rejaf, and Roton wetlands representing most, medium and least intensely cultivated ecosystems respectively were sampled for soil seed bank and vegetation based on methods by Gross (1990) and Kent and Coker (1992). Three to five transects at a distance of 500 $\mathrm{m}$ and $100 \mathrm{~m}$ away from the edge of the wetland were established in each wetland depending on its size (Cooper et al., 2006). Within each transect, six plots measuring $0.60 \times 0.60 \mathrm{~m}$ were randomly established taking into account edge effects. Within each plot, five-soil samples were collected, one at each corner and one in the center using a soil core $(12 \mathrm{~cm}$ depth and $4.5 \mathrm{~cm}$ diameter). The soil sample was divided as follows: $2 \mathrm{~cm}$ top soil was placed in a separate envelope and the $10 \mathrm{~cm}$ soil (bottom) in another envelope. This procedure was repeated for the plots in each site and every time keeping the $2 \mathrm{~cm}$ layers soil together in one envelop and the $10 \mathrm{~cm}$ layer in another envelop. Every plot measuring $0.60 \times 0.60 \mathrm{~m}$ had two composite soil samples consisting of $2 \mathrm{~cm}$ soil and $10 \mathrm{~cm}$ soil. The surface area sampled by the core was $15.9 \mathrm{~cm}^{2}$ and volume of soil was $190.8 \mathrm{~cm}^{3}$ thus in each plot
$953.8 \mathrm{~cm}^{3}$ of soil was collected. The soil samples were kept in sealed paper bags and stored for two months at room temperature $\left(25^{\circ} \mathrm{C}\right)$ and ambient humidity $(58 \%)$ to minimize infestation by pathogens such as moulds and to maintain seed viability (Baskin and Baskin, 2014).

\section{Seed germination}

A greenhouse germination experiment was set up, soil samples sieved in $2.0 \mathrm{~mm}$ mesh and spread in individual seed trays $(30 \mathrm{~cm} \times 27 \mathrm{~cm})$ on a substrate of sand excavated from beneath Khor Romulah lake floor (assumed to contain no viable seeds). Ten extra trays containing sand only were included as control. The trays were watered daily using water collected from the River Nile and seed germination monitored for nine months until no seedlings emerged. Germinating seeds (seedlings) were identified and removed to allow germination to continue. Seedlings that could not be identified were replanted and identified later using the Flora of Tropical East Africa and RBG and East Africa Herbarium 1952-2012.

To determine species richness and diversity for understory and seed bank, the total number of species counted was taken to be the species 
richness while for species diversity the ShannonWiener Diversity Index $(H)$ was calculated in Microsoft Excel using the following expression.

$$
H=-\sum_{i=1}^{N} p i \ln p i
$$

Where

$\mathrm{Pi}=$ proportion of total sample represented by species $i$

Obtained by dividing no. of individuals of species $\mathrm{i}$ by total number of individuals in sample.

$S=$ number of species,$=$ species richness

$\ln =$ natural logarithm

Seed density was computed by dividing seed abundance per plot by the volume of soil expressed in litres.

\section{Data analysis}

Data were analyzed in SPSS (version 20) and subjected to homogeneity of variance test to show whether all variables (species richness, diversity and density) measured deviated from normal. The results showed that all the variables deviated from normal hence Kruskal-Wallis (K$\mathrm{W})$ test was applied to show differences in soil seed banks from the three wetlands. The test of differences in medians were followed by DunnBonferroni's pairwise post-hoc test and adjustment of significant values (Zar, 2009). Data were also subjected to Analysis of Similarity Species Composition using non-metric multidimensional scaling (NMDS) in Community Analysis Package (CAP 5) Software. NMDS dissimilarity matrix was generated using Bray-Curtis to show whether species were shared between cultivated and uncultivated wetlands. Bray-Curtis distances were computed from species abundance data that were log transformed $\left(\log _{10} x+1\right)$ to improve normality
(Henderson and Seaby, 2014). Species Similarity Percentage (SIMPER) was calculated to determine the contribution of species to the dissimilarity species composition under intensive wetland cultivation. No seedlings germinated from the control trays.

\section{Results}

Sixty four species germinated from the soil seed bank belonging to 21 families dominated by Poaceae, Cyperaceae, Phyllanthaceae, Typhaceae and Brassicaceae. These included 53 terrestrial, eight wetland, three species occurring in both wetland and terrestrial and one unidentified species. Forty-seven species germinated from Mindiari (most cultivated) wetland; which included six wetland species dominated by Echinochloa colona (L.) Link and forty-one terrestrial annual species dominated by Phyllanthus niruri L., Mollugo nudicaulis Lam. and Anagallis arvensis L. followed by Eleusine indica (L.) Gaertn. and Eragrostis sp. Wolf. Wetland soil from Rejaf (moderately cultivated) germinated 28 species including four wetland species dominated by Typha capensis (Rohrb.) N.E. Br. and Cyperus difformis. There were 24 terrestrial perennial and annual species dominated by Phyllanthus niruri. Fifty-one species germinated from the Roton (least cultivated) wetland soil including seven wetland species dominated by perennial species such as Typha capensis, Cyperus difformis, Alopecurus sp. L., and annual species like Echinochloa colona, Portulaca sp. L., Phyllanthus niruri, Ocimum basilicum L. and Raphanus raphanistrum $\mathrm{L}$. These were also the dominant terrestrial annual species in Roton wetland. Terrestrial perennials namely Brachiaria ruzinensis Germ. and Evrard and Cyperus rotundus $\mathrm{L}$. dominated all the three wetlands while two wetland perennial species Cyperus difformis and Typha capensis were dominant in the all three wetlands (Table 1).

Table 1.Total abundance of wetland species recorded in the soil seed bank of most (Mindiari), moderate (Rejaf) and least (Roton) cultivated wetlands in Juba 


\begin{tabular}{lllll}
\hline Cultivation intensity & & Most & Moderate & Least \\
\hline Species & Family & Mindiari & Rejaf & Roton \\
Alopecurus sp. L. & Poaceae & 13 & 1 & 55 \\
Cyperus difformis L. & Cyperaceae & 73 & 52 & 373 \\
Cyperus esculentus L. & Cyperaceae & 1 & - & 3 \\
Echinochloa colona (L.) Link & Poaceae & 54 & 1 & 27 \\
Ipomoea aquatica Forssk. & Convolvulaceae & - & - & 2 \\
Typha capensis (Rohrb.) N.E. Br. & Typhaceae & 285 & 47 & 618 \\
Typha domingensis Pers. & Typhaceae & - & - & 16 \\
Pulicaria crispa Sch. Bip. & Asteraceae & 2 & - & - \\
\hline
\end{tabular}

The dominant terrestrial perennial species included Brachiaria ruzinensis, Cyperus rotundus and Eleusine indica and annuals such as Phyllanthus niruri, Anagallis arvensis and Raphanus raphanistrum.
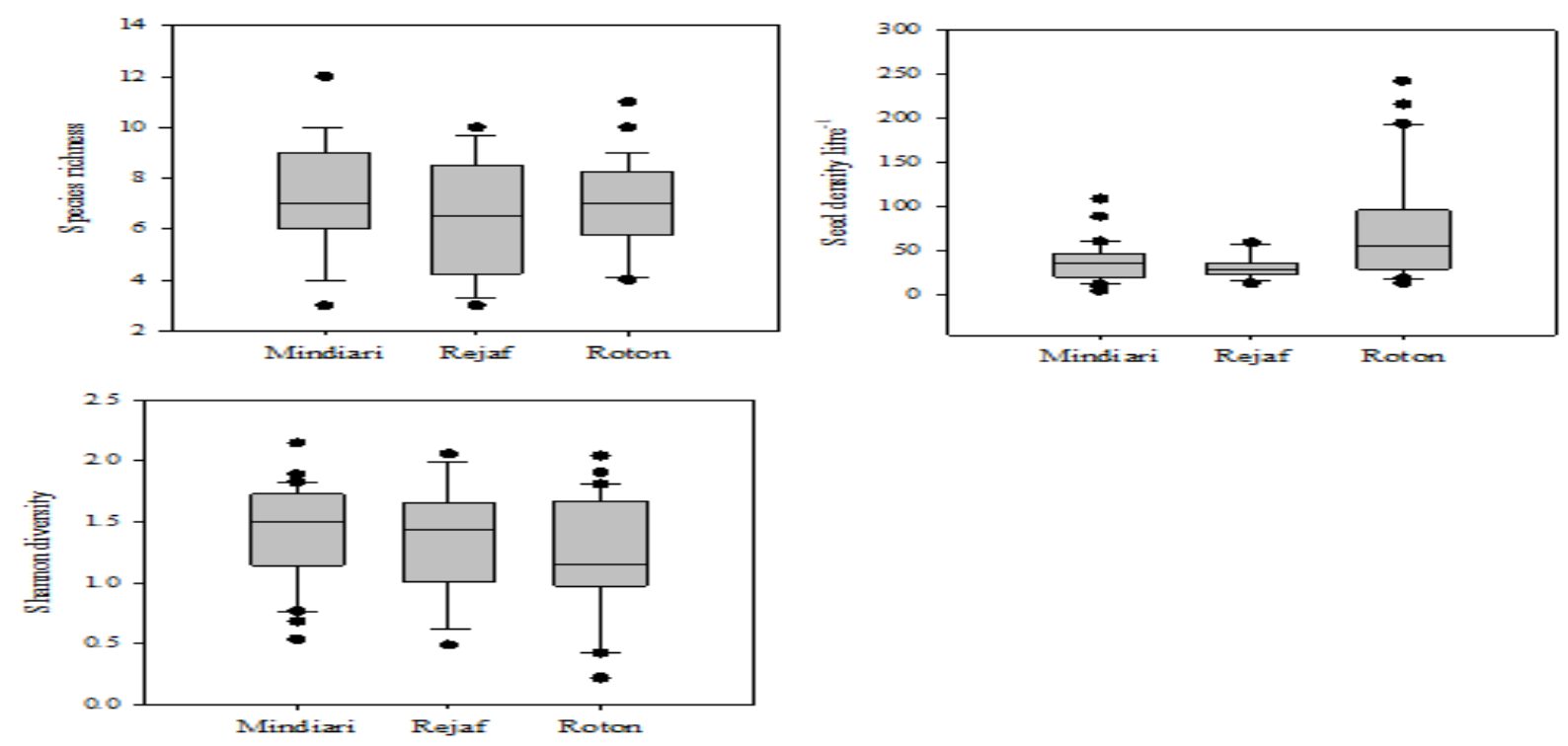

Figure 2. Species richness, Shannon diversity and density per litre of seeds from Mindiari, Rejaf and Roton wetlands in Juba. The thick line represents the median, the outer limits of the box represent first and third interquartile range. 
The median species richness was similar in Mindiari (7) and Roton (7) and slightly lower in Rejaf (6.5) but not significantly different (K-W X2 ${ }_{2}$ $=2.577, P>0.05)$. The median of Shannon-Wiener diversity was 1.5 in Mindiari wetland, 1.4 in
Rejaf wetland and 1.2 in Roton wetland but was not significantly different $\left(\mathrm{K}-\mathrm{W} \quad \mathrm{X}_{2}{ }_{2}=1.805\right.$, $P>0.05)$. However, median of seed density (56.1) was significantly higher in Roton than in Mindiari (36.7) and Rejaf (29.4) (Figure 2).

Table 2. Seed density in top and lower soil layers in most (Mindiari), moderate (Rejaf) and least (Roton) cultivated wetlands

\begin{tabular}{llll}
\hline Wetland & $\begin{array}{l}\text { Median per litre of } \\
\text { top 2 cm soil layer }\end{array}$ & $\begin{array}{l}\text { Median per litre of } \\
\text { lower 10cm soil layer }\end{array}$ & $\begin{array}{l}\text { Difference between top } \\
\text { and lower layer } \\
\text { Wilcoxon Z values }\end{array}$ \\
\hline Mindiari & 9.96 & 18.87 & $-2.70^{* *}$ \\
Rejaf & 9.44 & 15.73 & -1.29 \\
Roton & 31.98 & 19.40 & -0.99 \\
\hline
\end{tabular}

** $\mathrm{P}<0.01$

Fewer seeds were found in the top $2 \mathrm{~cm}$ soil profile of Mindiari and Rejaf wetlands. In Mindiari, the difference in median seed density between top and lower layers (top $2 \mathrm{~cm}$ layer $=$ 9.96, interquartile range $=39.84$, lower $10 \mathrm{~cm} 1=$ 18.87, interquartile range $=92.26$ ) was significant (Wilcoxon $W=363.60, \mathrm{P}=0.007$ ). In Rejaf, median seed density (top $2 \mathrm{~cm}$ layer $=9.44$, interquartile range $=48.23$, lower $10 \mathrm{~cm} \mathrm{l}=15.73$, interquartile range $=38.79$ ), was not significant. Although the median seed density in top layer was relatively high in Roton wetland (top $2 \mathrm{~cm}$ layer $=31.98$ interquartile range $=185.57$, lower $10 \mathrm{~cm}=19.40$, interquartile range $=159.36$ ) it was not statistically significant (Table 2). 

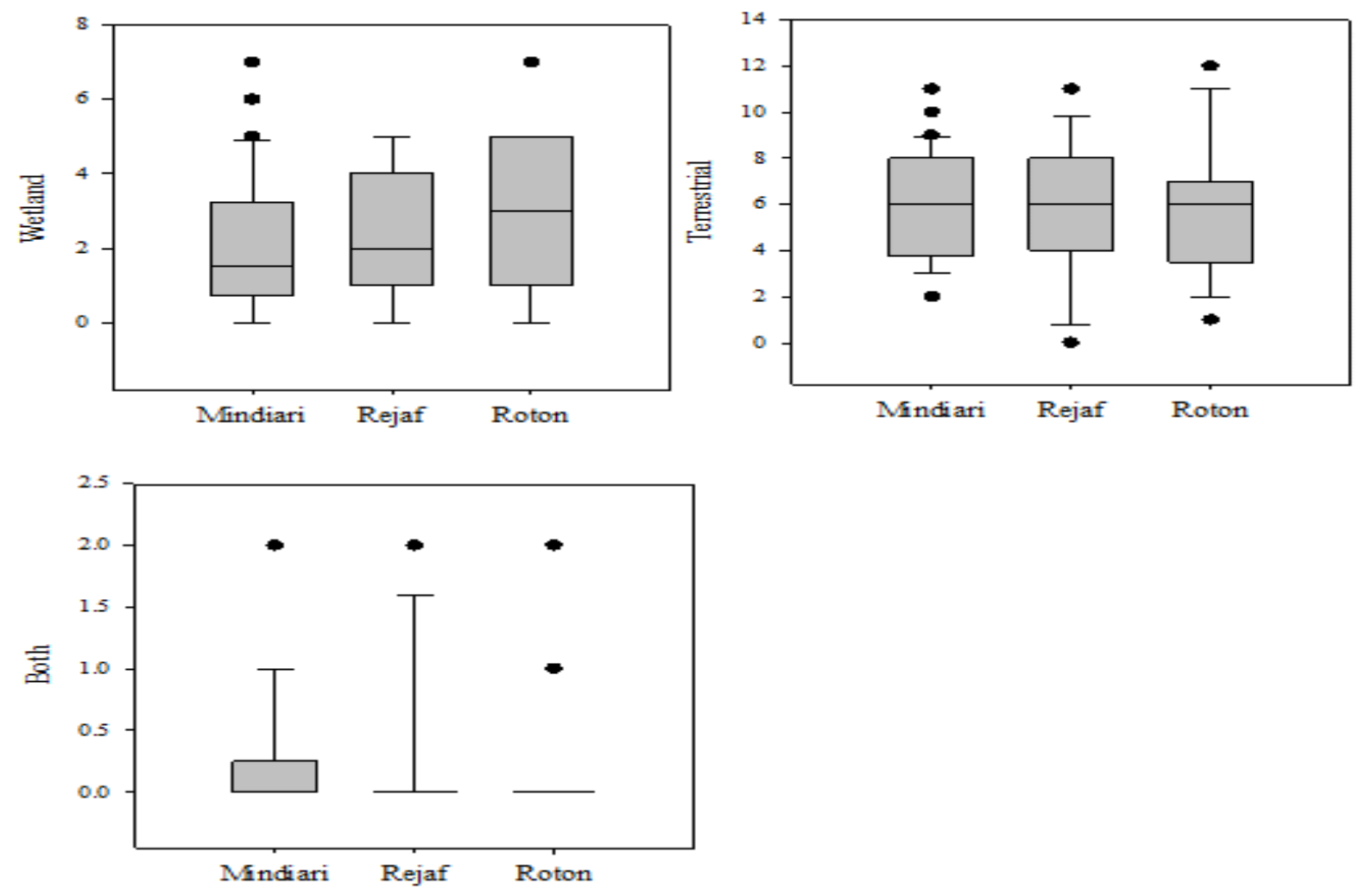

Figure 3. Soil seed bank species from Mindiari, Rejaf and Roton wetlands commonly found in wetland and terrestrial habitats.

The median of wetland species was slightly higher in the Roton wetland, but was not significantly different $\left(\mathrm{K}-\mathrm{W} \mathrm{X}{ }_{2}=2.515, P>0.05\right)$. Terrestrial species were represented in equal proportions in soil seed banks of Mindiari, Rejaf and Roton wetlands as shown by similar medians (Figure 3). The median of terrestrial annual species was similar in Mindiari and Rejaf wetlands bout lower for Roton wetland (3.5) though not statistically significant. Median of terrestrial perennial species was slightly higher in Roton wetland (5.07) $\left(\mathrm{K}-\mathrm{W} \mathrm{X}{ }_{2}=2.577, P>0.05\right)$ than Mindiari wetland (4.06) and Rejaf (4.03) though not significant (Figure 4). The median of families was also similar in Mindiari, Rejaf and Roton wetlands $\left(\mathrm{K}-\mathrm{W} \mathrm{X}{ }_{2}=2.796, P>0.05\right)$. 

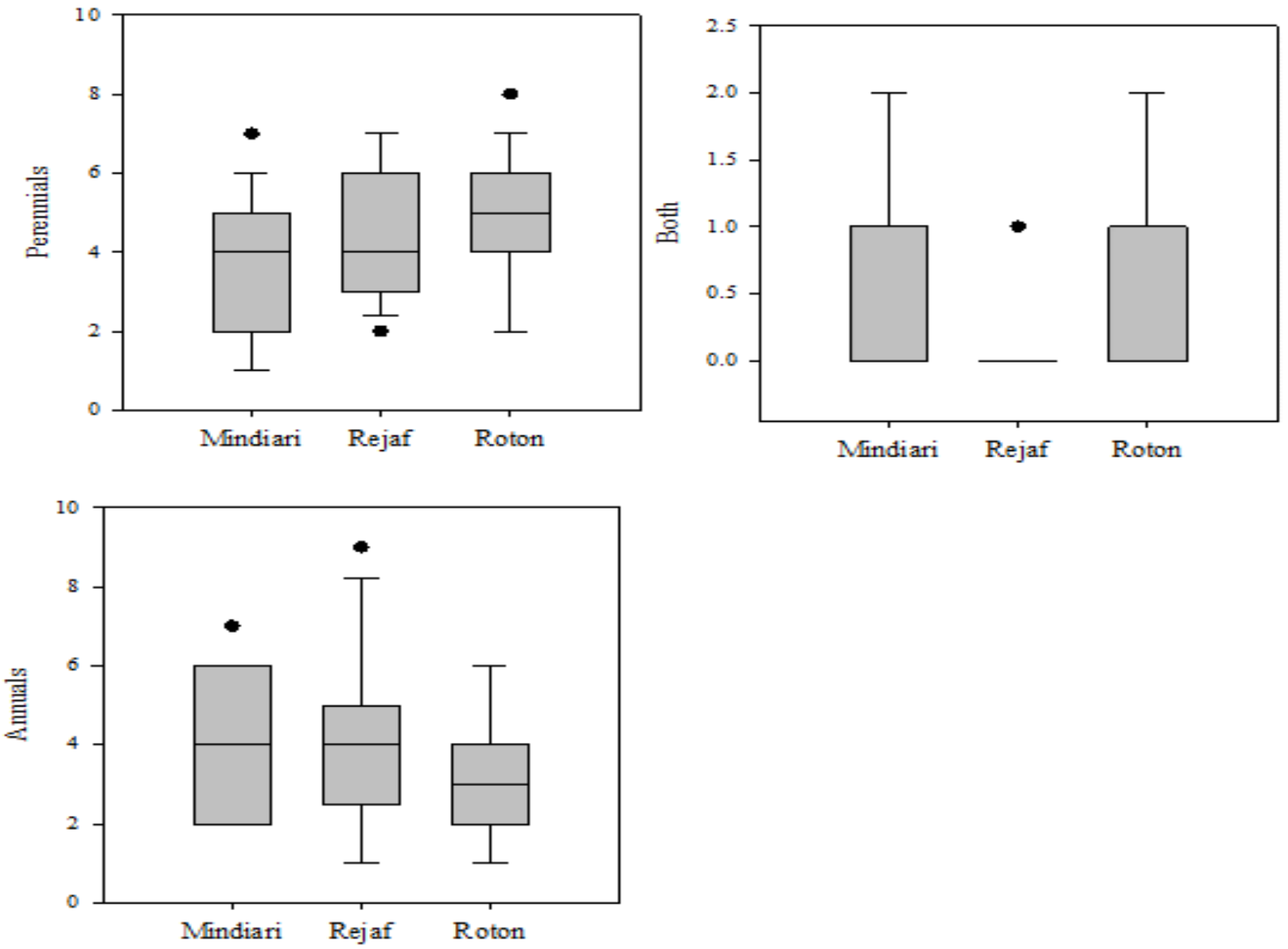

Figure 4. Life cycle of seeds from Mindiari, Rejaf and Roton wetlands.

Non woody species and sedges were similar in the three wetlands. Generally, woody species representation in the soil seed bank was scanty with only one terrestrial species (Euclea divinorum Hiern) germinating from the soil seed bank of Roton wetland (Figure 5). 


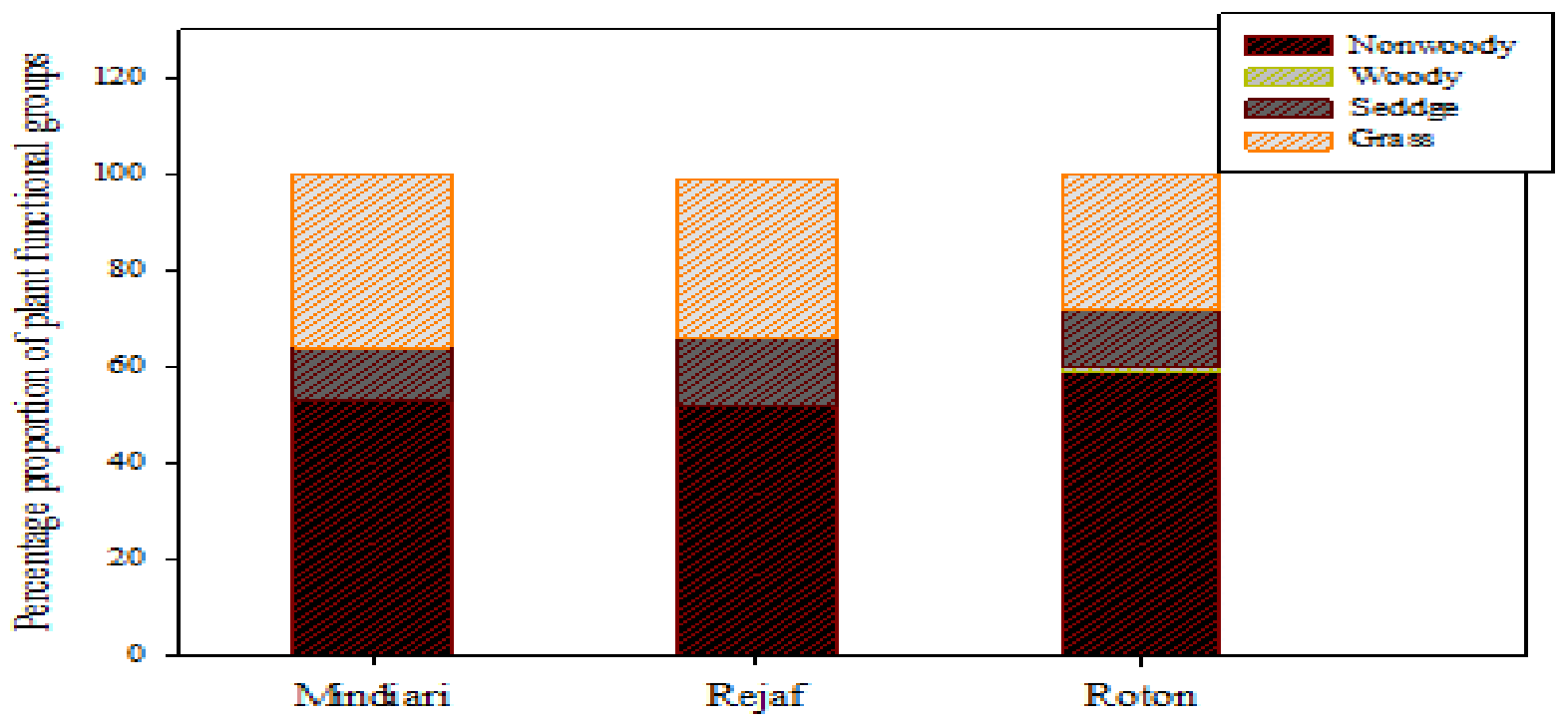

Figure 5. Proportion of plant functional groups in soil seed bank of Mindiari, Rejaf and Roton wetlands.

Results from two-dimensional NMDS ordination (iterations $=200$; stress $=0.15$ ) showed that species composition of cultivated wetlands was different from uncultivated wetlands (Figure 6). This finding was augmented by results from SIMPER, which showed 97.38 dissimilarity between Mindiari and Rejaf wetlands. Brachiaria decumbens, Digitaria longiflora, Cynodon nlemflehensis, Cynodon dactylon, Cyperus esculentus and Centurea inatongensis tended to occur in wetlands that had been cultivated most and moderately occurred in Mindiari and Rejaf wetlands respectively (Figure 6).

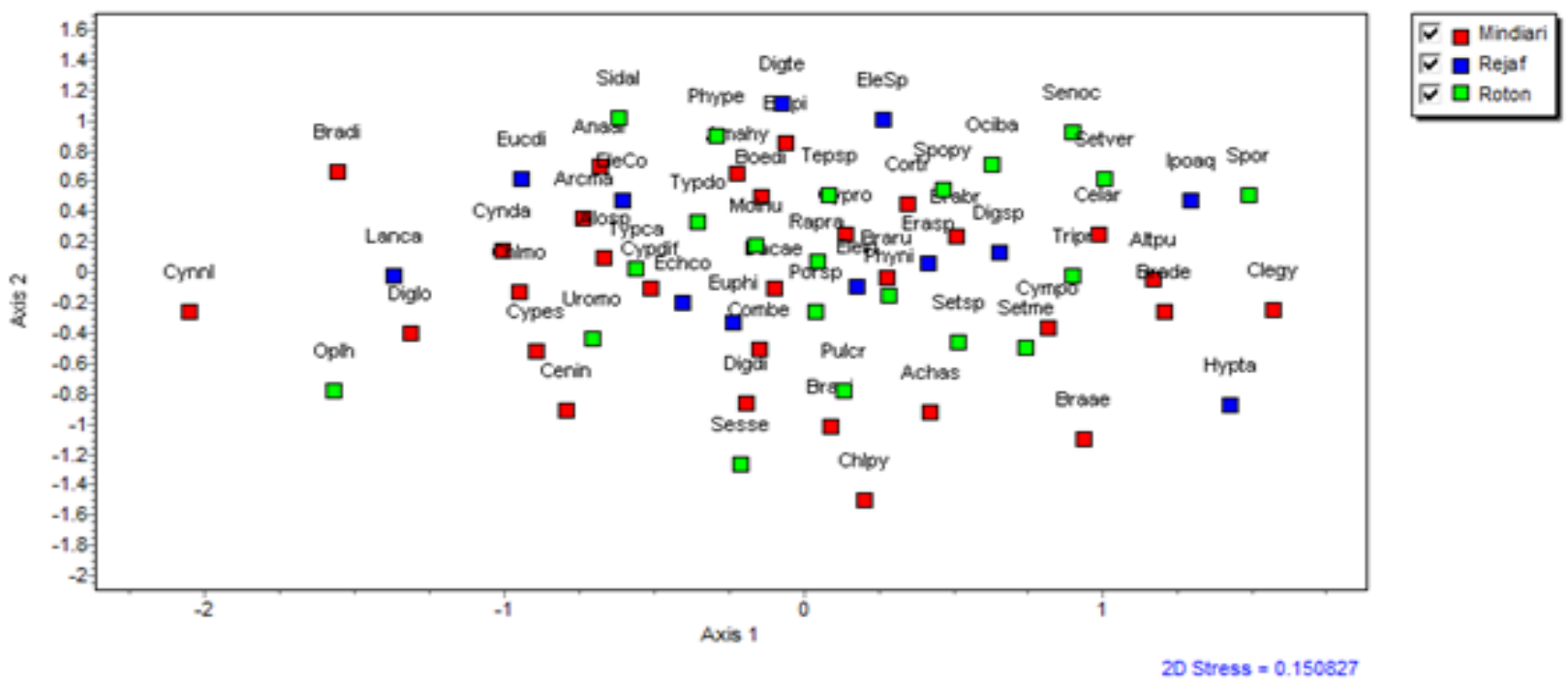

Figure 6. Axes 1 and 2 of the two dimensional NMDS ordination of soil seed bank species composition in most cultivated (Mindiari), moderately cultivated (Rejaf) and least cultivated (Roton) wetlands of Juba city 


\section{Discussion}

Results show that in total, 64 species germinated of which eight were wetland species. Species richness, diversity and number of terrestrial annual and perennial species was similar in all the three wetlands. While the median seed density was higher in Roton wetland and there were fewer seeds in the top $2 \mathrm{~cm}$ soil layer in Mindiari and Rejaf wetlands than in Roton wetland. Results from NMDS ordination showed that species composition of Mindiari and Rejaf was different from that of Roton wetland. Terrestrial species such as Brachiaria decumbens, Digitaria longiflora, Cynodon nlemflehensis, Euclea divinorum, Cynodon dactylon, and Centurea inatongensis were associated with Mindiari and Rejaf wetlands; representing most and least cultivated wetlands respectively. Wetland species such as Typha capensis and Cyperus difformis were associated with all the three wetlands.

These findings suggest that cultivation of wetlands has no influence on species richness and diversity. This did not support the prediction of high species richness and diversity in least cultivated wetland and low species richness in the heavily cultivated wetlands. Previous studies report mixed findings on species richness and diversity of soil seed banks in relation to the extent of wetland cultivation. Soil seed banks from cultivated wetlands may be species rich (Bao et al., 2014; Wang et al., 2016) or species poor (Middleton 2003; Amiaud and Touzard, 2004; Wang et al., 2015). Species that grow in wetlands require special adaptations to survive, grow and reproduce in a unique environment associated with waterlogging, frequent hydroperiod and heavy deposition of detrital matter (Shipley and Parent, 1991; Warwick and Brock, 2003; Fraser and Karnezis, 2005; Sakagami et al., 2020). However, human activities such as cultivation affects wetland hydrological regimes and water quality (Downs and Piégay, 2019) which influences plant growth in the wetlands (Dai et al., 2016; Byun, Nam and Kim, 2017; Hu et al.,
2020). Crop cultivation did not limit species richness and diversity in Mindiari and Rejaf wetlands which are classified as most and medium cultivated respectively. This might explain why species richness and diversity was similar in Mindiari, Rejaf and Roton wetlands irrespective of the extent of cultivation. At the same time, wetland soil seed bank species are known to be resilient (Ma et al., 2014) and survive episodes of cultivation (Galatowitch and van der Valk, 1996; Wang et al., 2016).

Seed density was lower and the top $2 \mathrm{~cm}$ soil layer had fewer seeds in Mindriari and Rejaf wetlands. It appears that cultivation reduces the soil seed density as it destroys wetland vegetation through direct vegetation removal thus limiting seed rain (Brown and Cahill Jr., 2020). In addition, seed density declines in cultivated wetlands due to seed losses arising from reduced viability (Eldridge and Lunt, 2010), limited seed dispersal into the site (Soomers et al., 2013) or increased germination because of improved aeration and light availability (Baskin and Baskin, 2006). Many factors affect the rate of seed loss including longevity of seeds, duration of cultivation and type of wetland (Leck and Brock, 2000; Middleton, 2003).This finding is in agreement with previous studies on seed density of cultivated wetlands. For example, a study in the prairie pothole depression wetlands of North America revealed that wetlands used for corn and soybean cultivation had low seed density compared to uncultivated natural wetlands (Galatowitsch and van der Valk, 1996). Similarly, seed density was lower in wetlands reclaimed for soybean and paddy rice growing in Sanjiang, China (Wang et al. 2015).

This study indicates that the three wetlands have similar number of annual (primary wetland species) and perennial (secondary wetland species) germinating from the soil seed bank. It would be logical to expect more annual species to germinate from the soil seed bank of Mindiari and Rejaf wetlands since most annuals have small seeds, are easily buried and incorporated 
into soil seed bank. However, this was not observed. Besides seed size, other factors influence seed availability in wetlands including dispersal mechanism, wetland type and seed predation (Chambers and MacMaho, 1994; van den Broek et al., 2005 and Fraaije et al., 2017). In terms of wetland vegetation regeneration, the findings are not in agreement with some of the previous studies. For instance, one of the earlier studies found that annuals such as Amaranthus rudis were more dominant in restored than undisturbed wetlands in the Canadian prairie pothole wetland ecosystems, while perennials such as Leersia oryziodes and Phragmites australis dominated undisturbed wetlands (Galatowitch and van der Valk, 1996). Another study revealed that restored Playa wetlands in America were dominated by mudflat annuals and lacked deeprooted emerged perennial species associated with natural wetlands (Beas et al., 2013). In this study, the dominant terrestrial annual species in Mindiari and Rejaf wetlands was Phyllanthus niruri, an annual species common in disturbed sites. Meanwhile Echinochloa colona; primary wetland species and Cyperus difformis and Typha capensis; secondary wetland species dominated the soil seed bank of all the wetlands. E. colona is an invasive species of seasonally flooded habitats, agricultural landscapes and pastures and has the potential to change species composition of wetland species (Zedler and Kercher, 2004; Hedja et al., 2009; Andrew, 2018). This has negative implications on natural regeneration because invasive species impede natural regeneration of wetlands (Vilá et al., 2011).

The NMDS results show that species composition of Mindiari (most disturbed), Rejaf (moderately disturbed) and Roton (least disturbed) wetlands was different, implying that cultivation influences species composition. Previous studies have shown that species composition in cultivated wetlands differed. For example, intact, restored and cultivated wetlands had different species composition with deep emergent invasive perennials and annuals associated with cultivated wetlands (Beas et al.,
2013). Similarly, species composition of natural wetland was different from that in the soybean and rice paddy fields (Wang et al., 2015). In contrast, Bao et al., (2014) reported similarity in plant species composition from seed bank of native and cultivated Pantanal wetland ecosystem probably due to flooding which acted as an environmental filter that restricted the establishment of invasive species such as Urochloa humidicola and favored growth of native species. Findings from this study also show that Typha capensis and Cyperus difformis occurred in all the three wetlands (Figure 6). High fecundity might explain the occurrence of these species in the seed bank of all the three wetlands. Typha species produce several tiny ( $<2 \mathrm{~mm}$ long) wind dispersed seeds which survive for long periods in the soil (van der Valk and Davis, 1976) and can regenerate by rhizomes (Redish, 1964). In many tropical wetlands, Typha sp. often forms dense canopy and excludes other wetland species (Keddy, 2010). Cyperus difformis is a prolific seed producer and completes vegetative and reproductive cycles in a short period of time (Holm et al., 1977). The family Cyperaceae is a common weed in wetlands planted with agricultural crops including paddy rice in many countries (May, 1981) and might explain the dominance of these species that belong to this family in both wetlands. Since Cyperus difformis and Typha capensis were dominating, these species could play an important role in the UN Decade of Ecosystem Restoration (2021-2030) which calls for efforts to restore degraded ecosystem including wetlands.

Of the eight-wetland species, Cyperus esculentus, Ipomoea aquatica and Pulicaria crispa were the least represented in all the three wetlands. Many factors may explain this including species ability to from soil seed banks which is associated with seed longevity (Honda 2008; Phartyal et al., 2019), changes in wetland water regime which influences recruitment (Shoemaker and Ervin, 2020) and germination conditions (Gonzalez and Ghermandi, 2012). These factors interactively explain low representation species in the seed banks and hence limit the potential of these 
species to contribute to natural vegetation regeneration of these wetlands.

\section{Conclusions and recommendations}

In conclusion, the study has shown that growing crops in wetlands i) does not influence species richness and diversity; ii) negatively affects seed density; and iii) alters species composition. Although wetland species were not significantly different in the three-wetland categories, dominance of canopy species belonging to Typhaceae and Cyperaceae indicates that these species are resilient to cultivation and could facilitate natural regeneration of wetlands. However, low seed density of other species suggests that additional seeding might be required to facilitate regeneration of these species in Mindiari and Rejaf wetlands. Further studies are recommended to examine the effect of duration of cultivation and flooding regimes on

\section{References}

Abernethy V. J. \& Willby N. J. (1999). Changes along a disturbance gradient in the density and composition of propagule banks in floodplain aquatic habitats. Plant Ecology 140: 177-190.

African Development Bank (2013). South Sudan: An infrastructure action plan, a program for sustained strong economic growth. Tunis, Tunisia.

Amiaud B. and Touzard B. (2004). The relationships between soil seed bank, aboveground vegetation and disturbances in old embanked marshlands of Western France. Flora 199, 25-35.

Andrew S. M. (2018). Invasive species Echinochloa colona reduces abundance and diversity of resident plant communities in tropical wetland. Open Journal of Ecology 8: 483-494.

Bao F., Pott A., Alves F. and Arruda F. R. (2014). Soil seed bank of floodable native and cultivated grassland in the Pantanal wetland: effects of flood gradient, season and wetland soil seed bank species richness, diversity, density and composition in cultivated wetlands. If species such as $E$. colona, $T$. domingensis with low seed densities are to be assisted through seeding, more research on germination and survival of these species is vital.

\section{Acknowledgment}

We are grateful to the staff of Institute of Environment and Natural Resource from Juba University for hospitality. In a special way, we thank staff from the greenhouse for their valuable time and support during seedling emergency experiment. Special regards to the Driver, for being brave. We thank, Makerere University Herbarium staff for assisting with identification of specimens. This work was supported by NORAD through NORHED grant number SSD13-0021.

species invasion Brazilian Journal of Botany 37:239-250.

Baskin, C. C. and Baskin, J. M. (2014). Seeds: Ecology, biogeography and evolution of dormancy and germination. New York: Academic Press.

Baskin C. C., Baskin J. M. and Chester W. (2019). Long term persistence of summer annuals in the seed banks of seasonally dewatered mudflats. Plant Ecology 220: 731-740.

Battaglia L. L. and Collins B.S. (2006). Linking hydroperiod and vegetation response in Carolina bay wetlands Plant Ecology (2006) 184:173 -185.

Beas B. J., Smith L. M., Hickman K. R., LaGrange T. G. and Stutheit R. (2013). Seed bank responses to wetland restoration: Do restored wetlands resemble reference conditions following sediment removal? Aquatic Botany 1087-15.

Blackwell Science, Ltd

Brock M.A (2011). Persistence of seed banks in Australian temporary wetlands. Freshwater Biology 56:1312-1327.

Brock, M.A. and Rogers, K.H. 1998: The regeneration potential of the seed bank 
of an ephemeral floodplain in South Africa. Aquatic Botany 61 (2), 123-35.

Brown C. and Cahill Jr. J. F. (2020). Standing vegetation as a coarse biotic filter for seed bank dynamics: effects of gap creation on seed inputs and outputs in a native grassland. Journal of vegetation Science. DOI: $10.1111 /$ jvs.12890

Byun C. Nam J. M. and Kim J. G (2017). Effects of flooding regime on wetland plant growth and species dominance in a mesocosm experiment. Plant Ecology 218: 517-527

Capon S. J. and Brock M. A. (2006). Flooding, soil seed bank dynamics and vegetation resilience of a hydrologically variable desert floodplain. Freshwater Biology 51: 206-223.

Capon S. J. (2007). Effects of flooding on seedling emergence from the soil seed bank of a large desert floodplain. Wetlands 27: 904-914.

Chambers J. C. and MacMahon J. A. (1994). A day in the life of a seed: Movements and fates of seeds and their implications for natural and managed systems. Annual review of ecology and systems 25: 263292.

Chen Y., Dong J., Xiao X., Ma Z., Tan K., Melville D., Li B., Lu H., Liu J. and Liu F. (2018). Effects of reclamation and natural changes on coastal wetlands bordering China's Yellow river sea from 1984-2015. Land Degradation and Development 30: 1533-1544.

Chen F., Zhang M., Wu Y. and Huang Y. (2020) Seed rain and seed bank of a draw-down zone and their similarities to vegetation under the regulated water-level fluctuation in Xiangxi River, Journal of Freshwater Ecology, 35:1, 57-71.

Cooper A., Mccann T and Bunce R. G. H. (2006). Influence of sampling intensity on vegetation classification and implications for environmental management. Environmental Conservation 33 118-127.

Dai X., Wan R., Yang G., Wang X. and Xu L. (2016). Responses of wetland vegetation in Poyang Lake, China to water-level fluctuations. Hydrobiologia 773:35-47.

Downs P. W. and Piégay H. Catchment-scale cumulative impact of human activities on river Channels in the late Anthropocene: implications, limitations, prospect. Geomorphology 338: 88-104

Eldridge D. J. and Lunt I. D. (2010). Resilience of soil seed banks to site degradation in intermittently flooded riverine woodlands. Journal of Vegetation Science 21: 157-166.

Fernando N. and Garvey W. (2013). The rapid water sector needs assessment and a way forward. Environment, Natural Resources, Water Resources and Disaster Risk Management Unit (AFTN3) Sustainable Development Department Country Department AFCE4. Africa Region.

Fraaije R. G. A. , Moinier S., van Gogh I., Timmers R., van Deelen J. J., Verhoeven J. T. A. and Soons M. B. (2017). Spatial patterns of water-dispersed seed deposition along stream riparian gradients. PLoS ONE 12(9): e0185247. https://doi.org/10.1371/journal.pone.0 $\underline{185247}$

Fraser L. H. and Karnezis J. P. (2005). A comparative assessment of seedling survival and biomass accumulation for fourteen wetland plant species grown under minor water-depth differences. Wetlands 25: 520-530.

Galatowitsch S. M. and van der Valk A. G. (1996). The Vegetation of Restored and Natural Prairie Wetlands. Ecological Applications 6: 102-112.

Gaudet, J. J., (1977). Natural drawdown on Lake Naivasha, Kenya, and the formation of papyrus swamps. Aquatic Botany 3:1- 47.

Gonzalez S. L and Ghermandi L. (2012). Comparison of methods to estimate soil seed banks: the role of seed size and mass. Community ecology 13: 238-242.

Griever R., Capon S. and Hadwen W. (2019). Resilence of coastal freshwater wetland vegetation subtropical Australia to rising sea levels and altered hydrology. 
Regional Environmental Change 19: 279292.

Gross, K. L. 1990. A comparison of methods for estimating soil seed banks. J. Ecol. 78:1079-1093.

Hejda, M., Pyšek, P. and Jarošík, V. (2009) Impact of invasive plants on the speciesrichness, diversity and composition of invaded communities. Journal of Ecology,

97, 393-403. https://doi.org/10.1111/j.13652745.2009.01480.x

Henderson, P. A. \& Seaby, R. M. H., 2014, Community Analysis Package Version 5, Pisces Conservation Ltd, Lymington, UK.

He M., Xin C., Baskin C. C., Li J., Zhao Y., An H., Sheng X., Zhao Y. and Ma M. (2020). Different response of transient and persistent seed bank of Alpine wetland to grazing disturbance on the Tibetan plateau. Plant Ecology. https://doi.org/10.1007/s11104-02004632-y

Holm L. G., Plucknett D. L., Pancho J. V., Herberger J. P. (1977). The world's worst weeds. distribution and biology. Honolulu, Hawaii, USA: University Press of Hawaii.

Honda Y. (2008). Ecological correlations between the persistence of the soil seed bank and several plant traits, including seed dormancy. Plant Ecology 196:301309.

Hu S., Niu Z., Chen Y., Li L., and Zhang H. (2017). Global wetlands: Potential distribution, wetland loss and status. Science of Total Environment. http://dx.doi.org/

10.1016/j.scitotenv.2017.02.001

Hu S., Chen Z., Vosátka M. and Vymazal J. ( 2020). Arbuscular mycorrhizal fungi colonization and physiological functions toward wetland plants under different water regimes. Science of the Total Environment.

https://doi.org/10.1016/j.scitotenv.202 0.137040

Kabiri S., Allen M., Okuonzia J. T., Akello B., Ssabaganzi R. and Mubiru D. (2020).
Detecting level of wetland encroachment for urban agriculture in Uganda using hyper-temporal remote sensing. https://doi.org/10.12688/aasopenres.1 $\underline{3040.1}$

Keddy P. A. (2010). Wetland ecology: Principals and conservation. Cambridge University Press. 497. ISBN 978-0-521519404.

Kent M. and Coker P. (1992). Vegetation Description and Analysis. A practical approach. John Wiley and Sons, New York.

Klimkowska A., Bekker R. M., Van Diggelen R. and Kotoswki W. (2010). Species traits shifts in vegetation and soil seed bank during fen degradation. Plant Ecology 206: 59-82.

Kottler E. J. and Gedan K. (2020). Seeds of change of change: Characterizing the seed bank of a migrating salt marsh. Annals of Botany 125: 335-344.

Kyalo N. D. and Heckelei T. (2018). Assessment of agricultural intensification and determinants of relative choice of land management systems in East African wetlands. Journal of rural Development 3: 821-830.

Leck M. A. and Brock M. A. (2000). Ecological and evolutionary trends in wetlands: Evidence from seeds and seed banks in New South Wales, Australia and New Jersey, USA. Plant species biology 15: 97112.Lenzewski N., Jensen K. and Ludewig K. (2020). Seed bank has the potential for colonizing urban ponds after reconstruction. Hydrobiologia. https://doi.org/10.1007/s10750-020$\underline{04365-0}$

Lomeling D. (2020). Predicting seasonal rainfall patterns and trends in Juba County, South

Sudan using artificial neutral networks. European Journal of Agriculture and Food Science. http://dx.doi.org/10.24018/ejfood.2020 .2 .2 .32

Ma M., Ma Z., Du G. (2014). Effects of water level on three wetlands soil seed banks on the Tibetan plateau. PLoS ONE 9(7): 
e101458.

doi:10.1371/journal.pone.0101458.

Matayaya G., Wuta M. and George Nyamadzawo G. (2017). Effects of different disturbance regimes on grass and herbaceous plant diversity and biomass in Zimbabwean dambo systems international journal of biodiversity science, ecosystem services \& management 3: 181-190.

May R. M. (1981). The world's worst weeds. Nature 290. 85-96

McCartney M., Rebelo, L. M., Senaratna Sellamuttu, S. de Silva S. 2010. Wetlands, agriculture and poverty reduction. Colombo, Sri Lanka: International Water Management Institute. 39 pages. (IWMI Research Report 137). doi: $10.5337 / 2010.230$

Middleton B. A. (2003). Soil seed banks and the potential restoration of forested wetlands after farming. Journal of Applied Ecology 40: 1025-1034.

Msofe N. K., Sheng L. and Lyimo J. (2020). Land use change trends and their driving forces in the Kilombero valley floodplain, Southern Tanzania. Sustainability 11, 505; doi:10.3390/su11020505.

Munishi S. and Jewitt G. (2019). Degradation of Kilombero valley Ramsar wetlands in Tanzania.

Physics and Chemistry of the Earth112: 216-227.

Peralta A. M. L., Sanchez A. M, Luzuriaga A. L. and Escudero A. (2017. Factors driving species assemblage in Mediterranean soil seed banks: from large $t$ the fine scale. Annals of Botany 117:1221-1228.

Phartyal S. S., Rosback S. Ritz C. and Poschlod P. (2019). Ready for change: Seed traits contribute to high adaptability of mudflat species to their unpredictable habitat. Journal of vegetation science 31 : 331-342.

Ramsar Convention Secretariat, (2013). The Ramsar Convention Manual: a guide to the Convention on Wetlands (Ramsar, Iran, 1971), 6th ed. Ramsar Convention Secretariat, Gland, Switzerland.
Rebelo L. M., Senay G. B. and McCarthy M.P. (2012). Seasonal variations in the inundation and evaporation in South Sudan, Earth Interactions 16: 1-19.

Rebelo L.M., McCartney M. P. and Finlayson C. M. (2010). Wetlands of Sub-Saharan Africa: distribution and contribution of agriculture to livelihoods. Wetland ecology and management 18: 557-572.

Reddish J. W. (1964). Studies of the germination and growth of cattail in relation to marsh management. Retrospective theses and dissertations.16857.

https://lib.dr.iastate.edu/rtd/16857

Ruley J. A, Amoding A., Tumuhairwe J. A., Basamba T. A. Opolot E. and OryemOriga H. (2019). Enhancing the phytoremediation of hydrocarbon contaminated soils in the Sudd wetlands, South Sudan using organic manure. Applied and environmental soil science. https://doi.org/10.1155/2020/4614286

Saatkamp A., Poschlod .P, Venable D. L. (2014). The functional role of soil seed banks in natural communities. In: Gallagher RS, ed. Seeds - the ecology of regeneration in plant communities. Wallingford, UK: CABI, 263-294.

Saha, T. K. and Pal, S. (2019). Emerging conflict between agriculture extension and physical existence of wetlands in postdam period in Atreyee river basin of Indo-Bangladesh. Environment and Development Sustainability 21: 14851505.

Sakagami J. I, Iwata Y., Nurrahma A. H. I., Siaga F., Junaedi A. and Yabuta S. (2020). Plant adaptations to anaerobic stress caused by flooding. IOP Conference Series: Earth and Environmental Science 418 (2020) 012080 IOP Publishingdoi:1 0.1088/1755-1315/418/1/012080

Salaria S., Howard R., Clare S. and Creed F. (2028). Incomplete recovery of plant diversity in restored Prairie wetland on agricultural landscapes. Restoration Ecology. https://doi.org/10.1111/rec.12890

Sanna, S., Eja, P., 2017. Recreational cultural ecosystem services: how do people describe 
the value? Ecosystem Services 26: 1-9.

Shi S., Chang Y., Wang G., Li Z., Hu Y., Liu M., Li Y., Li B., Zong M. and Huang W. (2020). Planning for wetland restoration potential based on the viability of the seed bank and the land-use change trajectory in the Sanjiang plain of China. Science of the Total Environment. https://doi.org/10.1016/j.scitotenv.202 $\underline{0.139208}$

Shipley B. and Parent M. (1991). Germination responses of 64 wetland species in relation to seed size, minimum time to reproduction and seedling relative growth rate. Functional Ecology 5: 111118.

Shoemaker C. M. and Ervin G. N. (2019). Factors at multiple scale influence recruitment from herbaceous wetland seed banks in the lower Mississipi alluvial valley. Wetlands.

https://doi.org/10.1007/s13157-01901248-6

Soomers H., Karssenberg D., Soons M. B., Verweij P. A., Verhoeven J. T. Aand and Wassen M. J. (2013). Wind and water dispersal of wetland plants across fragmented landscapes. Ecosystems 16: 434-451. DOI: 10.1007/s10021-012-9619y

Sosnowski A., Ghoneim E., Burke J. J., Hines E. and Halls J. (2016). Remote regions, remote data: A spatial investigation of precipitation, dynamic land covers, and conflict in the Sudd wetland of South Sudan. Applied Geography 69:51-64.

Stone L., Fryirs K. and Leishman M. (2018). Simulating the effect of environmental flow duration on seedling emergence from riparian seed banks of the Upper Hunter River, New South Wales. DOI: 10.1002/rra.3376

Touzard B., Amiaud B., Langlois E., Lemauviel S. and Clément B. (2002) The relationships between soil seed bank, Aboveground vegetation and disturbances in an eutrophic alluvial wetland of Western France. Flora 197: 175-185.

Van den Broek T., van Diggelen R. and Bobbink R. (2005). Variation in buoyancy of species in wetland ecosystems with different flooding dynamics. Journal of vegetation science 16:579-586.

Van der Valk, A. G., and Davis, C. B. (1976). The seed banks of prairie glacial marshes. Canadian Journal of Botany 54: 18321838.

Vandvik V., Klanderud K., Meineri E., Måren I. E and Töpper J. (2015). Seed banks are biodiversity reservoirs: species - area relationships above versus below ground. Oikos 000: 001-011.

Verhoeven J. T. A. and Setter T. M. (2010). Agricultural use of wetlands: opportunities and limitations. Annals of Botany 105: 155-163.

Vilá, M. and Weiner, J. (2004) Are invasive plant species better competitors than native plant species? - Evidence from pair-wise experiments. Oikos, 105, 229238. https://doi.org/10.1111/j.00301299.2004.12682.x

Wang G. D., Wang M., Lu X. G and Jiang M. (2015). Effects of farming on the soil seed banks and wetland restoration potential in Sanjiang Plain, Northeastern China. Ecological Engineering 77: 265-274.

Wang M., Wang G. D., Lu X. G., Jiang M. and Wang S. Z. (2016). Soil seed banks and their implications for wetland restoration along the Nongjiang River, Northeastern. http://dx.doi.org/10.1016/j.ecoleng.2 $\underline{016.05 .075}$

Wang G., Wang M., Lu X. and Jiang M. (2017). Duration of farming is an indicator of natural restoration potential of sedge meadows. Scientific reports/7:10692/ DOI:10.1038/s41598017-11429-0

Warwick N. W. M. and Brock M. A. (2003). Plant reproduction in temporary wetlands: the effects of seasonal timing, depth, and duration of flooding. Aquatic Botany 77: 153-167.

Webb M., Reid M., Capon S., Thoms M., Rayburg S. and James C. (2006). Are flood plain-wetland plant communities determined by seed bank composition or inundation periods? Sediment Dynamics and the Hydromorphology of Fluvial 
Systems (Proceedings of a symposium held in Dundee, UK, July 2006). IAHS Publ. 306, 2006.

Wehling P. (2020). The Nile and Its Catchment Area. In: Nile Water Rights. Springer, Berlin, Heidelberg. $\quad$ https://doi.org/10.1007/978-3662-60796-1_5

Wilusz D. C, Zaitchik B. F, Anderson M. C., Hain C. R.,Yilmaz M. T. and Mlandenova I. E. (2020). Monthly flooded area classification using low resolution SAR imagery in the Sudd wetland from 2001 to 2011. Remote Sensing of Environment 194: 205-2018.

Yang D., Liu W., Liu H. and Li W. (2018). Soil seed bank and its relationship to the aboveground vegetation in grazed and ungrazed oxbow wetlands of the Yangtze River, China. Environmental Engineering and Management Journal 17: 959-967.

Zar, J.H., (2009). Biostatistical analysis (5th ed). Englewood Cliffs, N.J: Prentice Hall.

Zedler, J. and Kercher, S. (2004) Causes and consequences of invasive plants in wetlands: opportunities, opportunists, and outcomes. Critical review in Plant Sciences, 23, 431-452. https://doi.org/10.1080/07352680490514673

Zhou L., Guan, D. Huang, X., Yuan, X. and Zhang M. (2020). Evaluation of cultural ecosystem services of Wetland Park. Ecological Indicators 114.

https://doi.org/10.1016/j.ecolind.2020.106286 